\title{
Agricultural economic production of Philippine calamansi industry: A basis for production local development plan
}

\author{
Ma. Florisa Quijano, $\mathrm{PhD}^{1}$ Gerald Quijano, $\mathrm{PhD}^{2}$ Rowell Diaz, $\mathrm{PhD}\left(\mathrm{c}^{3^{*}}\right.$ \\ ${ }^{1}$ Agricultural Marketing Faculty, Nueva Ecija University of Science and Technology, Fort Magsaysay Campus, \\ Palayan City, Nueva Ecija, Philippines. \\ ${ }^{2}$ Economics Faculty, Nueva Ecija University of Science and Technology, Fort Magsaysay Campus, Palayan \\ City, Nueva Ecija, Philippines. \\ ${ }^{3}$ Agribusiness Management Faculty, Nueva Ecija University of Science and Technology, San Isidro Campus, \\ San Isidro, Nueva Ecija, Philippines.
}

* Correspondence : Email Add: wellro0917@gmail.com

\begin{abstract}
:
This study examined the economics of Philippine Lime or Calamansi production in selected Cities and Municipalities in Nueva Ecija, Philippines. The study was conducted within the rural farming households' framework, which constitutes the Philippine agricultural sector's backbone, producing about 5.8 percent of the total national agricultural output with the Central Luzon area, including the portion of the locale of the study. Using quota sampling, data collected from 50 selected calamansi grower- farmers from top 5 producing area in Nueva Ecija, the study measured the profitability of and the production efficiency of calamansi production in the area. Using a formal interview schedule, primary data was obtained from the sampled farming households. The study revealed that the typical calamansi farmer in the area as reflected in the instrument, thirty-two (32) or 64\% which covers the majority of the respondents claimed that they fully owned the land they cultivated. Calamansi yield depends on its age as well. Fertilizer was found to harm output. Majority of them shared the same production and post-production practices, though a slight difference in terms of labor cost was observed. There were some who were already in the industry for quite a long time and learned other farming techniques and practices different from the conventional and were proven effective. For better efficiency, the land area cultivated, the farmers' educational status, accessibility to credit facility, and development of the rural areas and farmers' contact with the extension agents are some of the key issues to address. The local government in cities and municipalities may engage in an intensive campaign in encouraging capitalists to form cooperatives, processing and manufacturing houses to produce calamansi juice and other valuable products out of the calamansi fruit.
\end{abstract}

Keywords: production, calamansi, Philippine Lime, development plan, Nueva Ecija, economics. 


\section{Introduction}

In order to feed an increasing population, agricultural production in developed countries must be increased. [10]. In some parts of the world, calamansi is called Philippine Lime. But most Filipinos simply call it calamansi or calamondin, and in the Visayas and Mindanao, it is known as lemonsito. This fruit which is indigenous in the Philippines was identified by the Department of Agriculture (DA) as "one of the most important fruit crops grown in the country." In terms of area and production, it ranks fourth to banana, mango, and pineapple. Calamansi is grown on a large scale in the country due to its diverse uses. It is commercially produced in syrups, juices, tea, concentrates and purees. Additionally, it is used for treatment of cough and as natural anti-inflammatory medication. It is an abundant naturally-grown citrus tree and is one source of staple fruit juice in the Philippines [1].

Once familiarity with the fruit has been established in other countries, the scope for increasing exports and production is large. According to the Bureau of Agricultural Statistics (BAS), this marvelous fruit crop has contributed significantly to the export market. The country is the only global major exporter of calamansi, with juices accounting for the largest exported products. Major markets include USA, Japan, South Korea, Canada and Hong Kong. The top calamansi producer regions are CALABARZON, MIMAROPA and Central Luzon [15].

\section{Literature Review}

\section{Philippine Lime or Calamansi Production in the Philippines}

Calamondin (Citrofortunella microcarpa) fruits, known as kalamansi, are widely cultivated in the Philippines and used as a condiment in almost every famous dish made in the Philippines [17]. Calamondin belongs to the Family Rutaceae and is locally known as "calamansi.' Its primary usage is for souring food and juice/puree and food consumption. On the other hand, their food consumption needs must be fulfilled for a healthy, productive, and sustainable life [4]. There is no known variety of this commodity. This is available in the market whole-year-round with a peak harvesting period during July to September. It is propagated through grafting/budding with 'Calamandarin' as rootstock. In numerous government and private nurseries, planting materials are available.. Calamansi production requires not only land, but sufficient capital to start the business [2].

Both production and area had exhibited a decreasing trend for these six years with $199,675 \mathrm{MT}$ and 20,956 ha in 2013 to $164,050 \mathrm{MT}$ and 20,246 ha in 2013, respectively. In 2014, calamansi production in the Philippines declined by $2.04 \%$ to $160,740.43$ metric tons (MT) from 164,091.06 MT in 2013 (2016). The annual decline in production is higher than those as manifested by the average annual negative growth rate of $-3.83 \%$ and $-0.68 \%$, respectively. On a regional level, the main growing areas are MIMAROPA (6,872 ha), Central Luzon (1,734 ha), and Ilocos Region (1,026 ha) in Luzon, while in Mindanao; it is in Davao Region $(1,797$ ha), CARAGA $(1,412$ ha) and Zamboanga Peninsula $(1,077$ ha). Complementation of Luzon's production with that of Mindanao assures the availability of fresh fruit all-year round [14].

In the same study by Espino and Espino (n.d.), just like in total production and area, the average yield (MT/ha) had been steadily decreasing over these six years from $9.53 \mathrm{MT} / \mathrm{ha}$ in 2008 to $8.10 \mathrm{MT} / \mathrm{ha}$ in 2013 . This is translated into a negative average annual growth rate of 3.18 , which was almost the same magnitude as total production $(-3.83)$. Out of the total 
production of 164,050 MT in 2013, ninety-three (93\%) of the volume was used as net food disposable while the remaining percentage was considered for export and feed/waste.

During this six-year period, calamondin's annual farmgate price had increased with the highest price at P23.13/kg reported in 2012. This had declined to P17.73/kg in 2013. This price fluctuation was due to the oversupply of calamansi fruits during peak season.

With this scenario, there is a need to provide new markets and agribusiness technologies for calamansi products such as cooperatives, processors, commercial establishments, and restaurants to attain prices, especially during peak season. Agribusiness firms that take advantage of rising opportunities to implement emerging innovations and incorporate them into marketable service resources can benefit from systemic changes. [3].

\section{Materials and Methods}

The descriptive method of analysis was used in the thesis. Descriptive type of research is used to obtain information concerning the current status of conditions in a situation. In the collection and analysis of data, the researcher used quantitative and qualitative approaches and techniques. Survey questionnaires were administered to the respondents of the study and interviews to have a deeper and more comprehensive presentation. The study was conducted in the top five calamansi-producing cities and municipalities of Nueva Ecija, namely: San Leonardo, Cabanatuan City, Palayan City, Cabiao, and Peñaranda.

Nueva Ecija is the third leading calamansi producer in the Philippines (Philippine Statistics Authority, 2018). Agriculture is the main industry in the province. An agricultural system based on the maximum potential of biodiversity (functional agro) is an opportunity to build a resilient system in which both food production and nature can flourish. [7]. As the world population and food production demands rise, keeping agricultural soils and landscapes healthy and productive is paramount to sustaining local and global food security and the flow of ecosystem services to society [8]. Some of the products that are produced in great quantities are rice, onion, mango, calamansi, banana, garlic, and different types of vegetables. With the skills, strong perseverance and diligence of calamansi growers in Nueva Ecija, it is considered the top 3 calamansi producer province of the country. In April to June 2019, the country produced 18.02 thousand metric tons of calamansi $2 \%$ lower than the 18.39 thousand metric tons recorded during the same period of 2018 (Philippine Statistics Authority, 2018). MIMAROPA remained the top producer of calamansi with $38.9 \%$ share in the total national production. Zamboanga Peninsula ranked second with $13.2 \%$ share and Central Luzon with $10.9 \%$.

San Leonardo being the top producer of calamansi in the province is basically an agricultural town where agriculture plays a significant role in the municipality's income. It has the highest number of non-bearing and bearing calamansi trees, a total of 193,690. Next to San Leonardo is Cabanatuan City with 153,995 trees, followed by Palayan City with 142,575 trees. Cabiao and Peñaranda were also among the top 5 producing municipalities.

Calamansi farming was introduced in the province through the Batangueño migrants. Many of the growers say that Brgy. Isla and Aduas of Cabanatuan City were among the very first barangay to engage in calamansi farming in the province. Among the top five producing cities and municipalities, it was only in Bryg. Aulo in Palayan City where calamansi processing plant is continually operating. 
They were selected using a quota sampling technique. Quota sampling is a nonprobability sampling method in which a researcher creates a sample involving individuals representing a population. The researcher chose these individuals according to specific traits or qualities. The researcher decided and created quotas so that the market research samples can be useful in collecting data. These samples can be generalized for the entire population [16].

The study involved the calamari growers as the main respondents, and the provincial, city, and municipal agriculturists from LGUs concerned in Nueva Ecija as secondary sources of data. The distribution of respondents is presented in Table 1. Fifty (50) respondent-growers served as respondents. The study respondents were also identified based on the characteristics given by the data from the Provincial Agriculturist Office.

For the calamansi growers, the first part of the questionnaire includes the aspects of calamansi industry: inputs provision, production, post-production, and marketing. The second part focused on problems and constraints encountered by the respondents on each of the said aspects. The researcher employed an unstructured interview for the city/municipal/provincial agriculturists to get the necessary secondary data.

The reliability of the instrument was established using the test-retest method. The test-retest method is the instrument's administration with at least two-week interval prior to the actual distribution and accomplishing of the instrument, which was done among the non-respondent growers of the study. The results of the two tests were correlated using the Pearson Product Moment of Correlation formula. The reliability coefficient of 0.81 indicated that the instrument is reliable, i.e. it could give consistent results.

Face validation was also used in this study. After constructing the instrument, the researcher consulted his dissertation adviser and statistician and other experts in the field of agriculture. In this manner, the questionnaire was polished after undergoing many revisions to incorporate the suggestions being made during consultations.

\section{Results and Discussion}

\section{Production}

The production aspect encompasses land preparation, transplanting, and farm maintenance activities such as irrigation, fertilization, pruning, weeding, and pest, and disease prevention. These activities are sometimes called "cultural management" of the plant. Besides, progressive production technologies should be investigated to improve yields and minimize production constraints [12]. To have a clearer picture of the production process, Figure 1 elucidates this. 


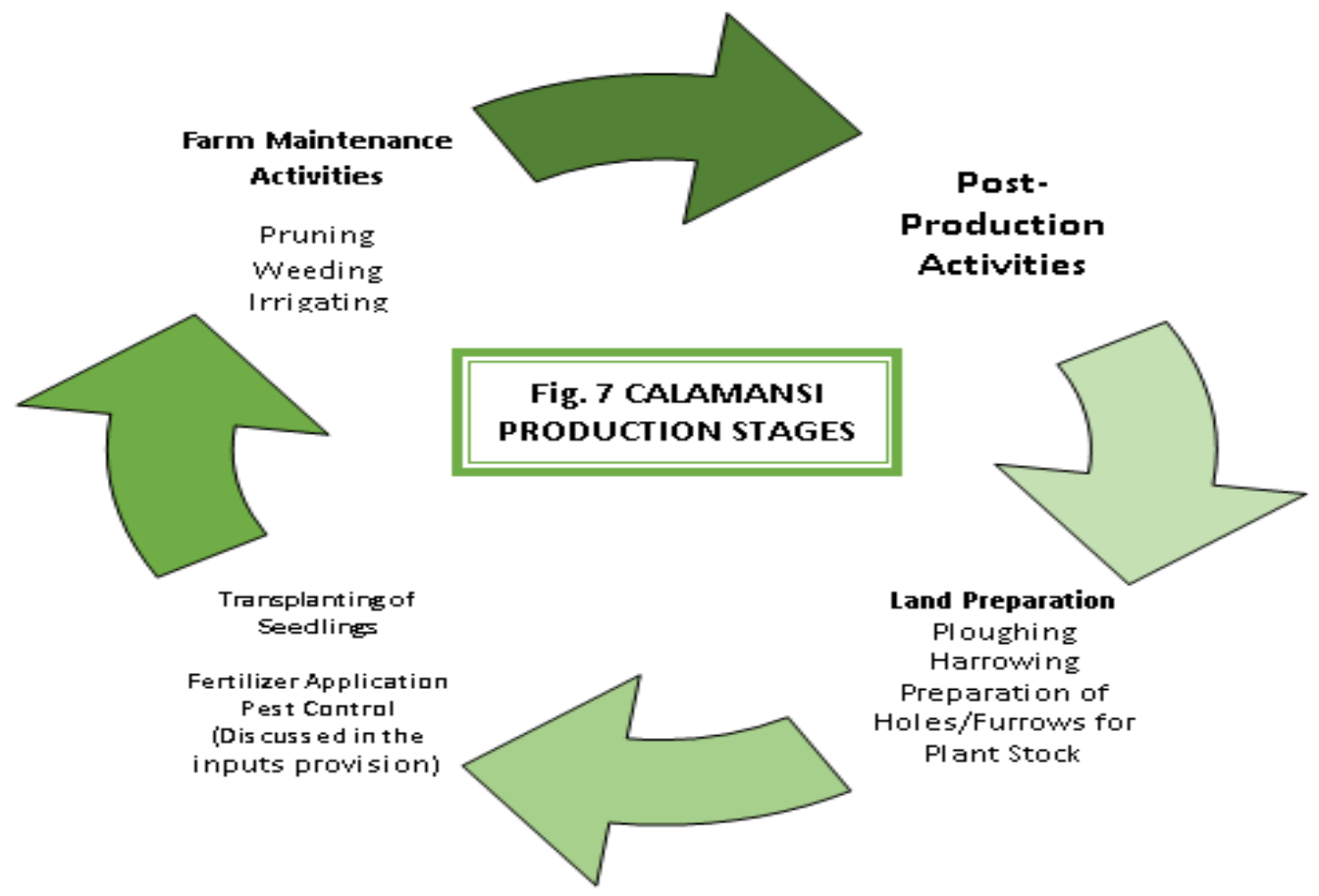

Calamansi farming begins with preparing the field, the purpose of which is to provide the required soil conditions that will enhance the productive establishment of the young tree in the nursery. After preparing the soil before the start of planting activities, the grower must prepare the planting holes in which the appropriate distance between the seedlings is one of the key decisions as this is a significant factor in the growth of the roots. Once the planting holes are already prepared, the grower is now able to transplant the seedlings. Transplanting is also an important activity since it prepares the tree for ground utilization. It must be done properly to ensure that the plant develops healthily.

After transplanting, the grower is now ready to provide the required nutrients for plants through the application of fertilizer and pest/insect control. Such operations, apart from labor costs, are often linked to costly farming practices. Apart from fertilizer and insect spray, the grower must also maintain a safe and healthy plant environment by maintenance practices such as weeding, pruning, and irrigation.

All the previously mentioned activities have an important role to play to have a good harvest and, therefore, add value to the crop to sell it at a good price.

\section{Land Preparation}

Land preparation is composed of plowing and harrowing of soil and seedbed preparation. Changes in land biophysical characteristics can contribute to a shift in the equilibrium, abundance, and increased vulnerability of floods and droughts [9].

\section{Ploughing}

Hand tractors/rotavator/toner or the carabao are the machines and animals used in ploughing the soil for preparation. Table 1 presents the ploughing cost per hectare across the top five producing cities and municipalities of calamansi in Nueva Ecija. 
Table 1. Ploughing Cost per Hectare

\begin{tabular}{|c|c|c|c|c|c|c|c|c|c|c|}
\hline \multirow[b]{2}{*}{ Year } & \multicolumn{2}{|c|}{ San Leonardo } & \multicolumn{2}{|c|}{ Cabanatuan } & \multicolumn{2}{|c|}{ Palayan } & \multicolumn{2}{|c|}{ Cabiao } & \multicolumn{2}{|c|}{ Peñaranda } \\
\hline & $\begin{array}{c}\text { No. of } \\
\text { Laborers }\end{array}$ & $\begin{array}{c}\text { Contract } \\
\text { Amount } \\
/ \text { Ha. }\end{array}$ & $\begin{array}{c}\text { No. of } \\
\text { Laborers }\end{array}$ & $\begin{array}{c}\text { Contract } \\
\text { Amount } \\
\text { /Ha. }\end{array}$ & $\begin{array}{c}\text { No. of } \\
\text { Laborers }\end{array}$ & $\begin{array}{c}\text { Contract } \\
\text { Amount } \\
\text { /Ha. }\end{array}$ & $\begin{array}{l}\text { No. of } \\
\text { Laborers }\end{array}$ & $\begin{array}{c}\text { Contract } \\
\text { Amount } \\
/ \text { Ha. }\end{array}$ & $\begin{array}{l}\text { No. of } \\
\text { Laborers }\end{array}$ & $\begin{array}{c}\text { Contract } \\
\text { Amount } \\
/ \text { Ha. }\end{array}$ \\
\hline 2019 & $1-2$ & P3,000 & $1-2$ & P3,500 & $1-2$ & P3,500 & $1-2$ & P3,000 & $1-2$ & P3,000 \\
\hline 2018 & $1-2$ & 3,000 & $1-2$ & 3,500 & $1-2$ & 3,500 & $1-2$ & 3,000 & $1-2$ & 3,000 \\
\hline 2017 & $1-2$ & 3,000 & $1-2$ & 3,500 & $1-2$ & 3,500 & $1-2$ & 3,000 & $1-2$ & 3,000 \\
\hline 2016 & $1-2$ & 3,000 & $1-2$ & 3,500 & $1-2$ & 3,500 & $1-2$ & 3,000 & $1-2$ & 3,000 \\
\hline
\end{tabular}

Data show that plowing's total cost was highest in Cabanatuan, San Leonardo, Palayan, and Peñaranda and lowest in Cabiao. It was higher by P500.00 Differences in the amount depending on the demand and demographics disclosed by the growers. The demographic profile of Cabanatuan City may be the reason for higher ploughing costs since most of the population were already confined to malls and other commercial establishments. Palayan City is somewhat hilly and mountainous ploughing of lands is more difficult; thus, the ploughing cost was higher. In Peñaranda and San Leonardo, calamansi plants used to be planted with mangoes before such that tilling of soil can be difficult, hence a higher ploughing cost.

The cost of ploughing already included the use of tractor, expenses for fuel and labor. Some calamansi farmers have "kasama" and the carabao was used in the land preparation. The use of farm animal can also be contracted by other growers for a contract price of $\mathrm{P} 2,500.00$ - P 3,000.00 per hectare.

\section{Harrowing}

After ploughing, growers had to pulverize, smoothen the soil and remove weeds before preparing the transplanting activity holes. Rotavator was used for second soil tillage, while toner was used to complete tillage operations, especially in the preparation of holes. For drylands, they did this twice. The productivity of dryland farming is influenced by soil fertility, land conservation, vegetation, technology, institution and socio-economic condition of the community [5].

Table 2 presents the harrowing cost per hectare across the five cities and municipalities.

\section{Table 2. Harrowing Cost per Hectare}

\begin{tabular}{|c|c|c|c|c|c|c|c|c|c|c|}
\hline \multirow[b]{2}{*}{ Year } & \multicolumn{2}{|c|}{ San Leonardo } & \multicolumn{2}{|c|}{ Cabanatuan } & \multicolumn{2}{|c|}{ Palayan } & \multicolumn{2}{|c|}{ Cabiao } & \multicolumn{2}{|c|}{ Peñaranda } \\
\hline & $\begin{array}{c}\text { No. of } \\
\text { Laborers }\end{array}$ & $\begin{array}{c}\text { Contract } \\
\text { Amount } \\
\text { /Ha. }\end{array}$ & $\begin{array}{c}\text { No. of } \\
\text { Laborers }\end{array}$ & $\begin{array}{c}\text { Contract } \\
\text { Amount } \\
\text { /Ha. }\end{array}$ & $\begin{array}{c}\text { No. of } \\
\text { Laborers }\end{array}$ & $\begin{array}{c}\text { Contract } \\
\text { Amount } \\
\text { /Ha. }\end{array}$ & $\begin{array}{c}\text { No. of } \\
\text { Laborers }\end{array}$ & $\begin{array}{c}\text { Contract } \\
\text { Amount } \\
\text { /Ha. }\end{array}$ & $\begin{array}{c}\text { No. of } \\
\text { Laborers }\end{array}$ & $\begin{array}{c}\text { Contract } \\
\text { Amount /Ha. }\end{array}$ \\
\hline 2019 & $1-2$ & P3,000 & $1-2$ & P3,500 & $1-2$ & P3,500 & $1-2$ & P3,000 & $1-2$ & P3,000 \\
\hline 2018 & $1-2$ & P3,000 & $1-2$ & P3,500 & $1-2$ & P3,500 & $1-2$ & P3,000 & $1-2$ & P3,000 \\
\hline 2017 & $1-2$ & P3,000 & $1-2$ & P3,500 & $1-2$ & P3,500 & $1-2$ & P3,000 & $1-2$ & P3,000 \\
\hline 2016 & $1-2$ & P3,000 & $1-2$ & P3,500 & $1-2$ & P3,500 & $1-2$ & P3,000 & $1-2$ & P3,000 \\
\hline
\end{tabular}

Harrowing costs in Palayan City were the highest, while other municipalities' costs were just the same. It was higher by P500.00. Harrowing may vary depending on the soil composition. Availability and demand for farm equipment can also be a factor for a pull in the cost. Palayan growers said that many of their agricultural lands were uplands, and at the same time, the soil was also dry. They truly had to employ the need to use machines to pulverize the soil. This was the reason why the labor cost was high. Some growers who already acquired 
farm machinery like rotavator only paid the labor cost. Labor cost per day was estimated at P200.00-P500.00. To some, they did the harrowing to lessen the farming cost. Under the value chain analysis, this interplay is a primordial factor in calamansi farming.

\section{Holes and Furrows Preparation for Plant Stock}

Boring holes for calamansi seedlings is a common practice. The depth of the hole varied depending on the size of a calamansi tree. Usually, growers dug a hole about 14-16 inches deep and around 14-16 inches wide. These measurements are suited for medium to large size calamansi tree. If the grower prefers a smaller tree, the holes are around 6-8 inches deep or until it reaches that part called "dugtungan" in the trunk of a tree as a result of grafting. Introducing some mixture of compost and commercial fertilizers before the stock is laid can make a healthy and robust plant.

Aside from plant holes, growers also need to prepare furrows or "tudlings" for straight alignment of trees and as water channels to irrigate plants. The furrow system was used for row crops such as the calamansi. Furrows were plowed between crop rows, and water was run in the furrows. The interrelationship between water and food security is that water and food security will face major challenges under climate change conditions [11].

According to growers, in the early stages of tree planting, one furrow alongside the tree row may be sufficient. Still, as the trees developed then, two or more furrows can be constructed to provide sufficient water. Sometimes, a special zigzag system was used to improve the spread of water. The demand for water has increased while the supply has been stagnant [13].

The grower incurred additional cost in the preparation of holes for plant stock as well as in the preparation of irrigation furrows. Table 3 shows the holes/furrows preparation cost per hectare.

Table 3. Holes/Furrows Preparation Cost per Hectare

\begin{tabular}{|c|c|c|c|c|c|c|c|c|c|c|}
\hline & \multicolumn{2}{|c|}{$\begin{array}{c}\text { San } \\
\text { Leonardo }\end{array}$} & \multicolumn{2}{|c|}{ Cabanatuan } & \multicolumn{2}{|c|}{ Palayan } & \multicolumn{2}{|c|}{ Cabiao } & \multicolumn{2}{|c|}{ Peñaranda } \\
\hline Year & $\begin{array}{c}\text { No. of } \\
\text { Laborers }\end{array}$ & $\begin{array}{c}\text { Contract } \\
\text { Amount } \\
\text { /Ha. }\end{array}$ & $\begin{array}{c}\text { No. of } \\
\text { Laborers }\end{array}$ & $\begin{array}{c}\text { Contract } \\
\text { Amount } \\
\text { /Ha. }\end{array}$ & $\begin{array}{c}\text { No. of } \\
\text { Laborers }\end{array}$ & $\begin{array}{c}\text { Contract } \\
\text { Amount } \\
\text { /Ha. }\end{array}$ & $\begin{array}{c}\text { No. of } \\
\text { Laborers }\end{array}$ & $\begin{array}{c}\text { Contract } \\
\text { Amount } \\
\text { /Ha. }\end{array}$ & $\begin{array}{c}\text { No. of } \\
\text { Laborers }\end{array}$ & $\begin{array}{c}\text { Contract } \\
\text { Amount } \\
\text { /Ha. }\end{array}$ \\
\hline 2019 & $2-3$ & $\mathrm{P} 1,500$ & $2-3$ & $\mathrm{P} 1,800$ & $2-3$ & $\mathrm{P} 1,800$ & $2-3$ & 1,500 & $2-3$ & $\mathrm{P} 1,500$ \\
\hline 2018 & $2-3$ & $\mathrm{P} 1,500$ & $2-3$ & $\mathrm{P} 1,800$ & $2-3$ & $\mathrm{P} 1,800$ & $2-3$ & 1,500 & $2-3$ & $\mathrm{P} 1,500$ \\
\hline 2017 & $2-3$ & $\mathrm{P} 1,500$ & $2-3$ & $\mathrm{P} 1,800$ & $2-3$ & P1,800 & $2-3$ & 1,500 & $2-3$ & $\mathrm{P} 1,500$ \\
\hline 2018 & $2-3$ & $\mathrm{P} 1,500$ & $2-3$ & $\mathrm{P} 1,800$ & $2-3$ & $\mathrm{P} 1,800$ & $2-3$ & 1,500 & $2-3$ & $\mathrm{P} 1,500$ \\
\hline
\end{tabular}

Cabanatuan and Palayan growers paid higher labor cost on holes/furrows preparation at P1,800.00/ha. as compared to San Leonardo, Peñaranda and Cabiao at P1,500.00 for 2-3 laborers. This means that in a day's work, a worker gets Php300.00. as payment, but in municipalities, normally they would only get paid at P250.00. Since the prevailing daily wage rate for agricultural sector set by the Department of Labor is P 350.00, it can be noted that most of them in the province were underpaid. There were few growers who said that they only get P200.00 for a day of work. Usually, it took them two days to complete these activities per hectare. 


\section{Farm Implements Used}

Table 4 presents the farm implements used by the calamansi-respondents.

Table 4. Farm Implements Used by the Calamansi Growers

\begin{tabular}{|c|c|c|c|c|c|c|c|c|c|c|c|c|}
\hline $\begin{array}{c}\text { Farm } \\
\text { Implements }\end{array}$ & \multicolumn{2}{|c|}{$\begin{array}{c}\text { San } \\
\text { Leonardo }\end{array}$} & \multicolumn{2}{|c|}{ Cabanatuan } & \multicolumn{2}{|c|}{ Palayan } & \multicolumn{2}{|c|}{ Cabiao } & \multicolumn{2}{|c|}{ Peñaranda } & \multicolumn{2}{|c|}{ Total } \\
\hline Items & $\mathbf{F}$ & $\%$ & $\bar{f}$ & $\%$ & $\mathbf{f}$ & $\%$ & $\bar{f}$ & $\%$ & $\mathbf{f}$ & $\%$ & $\mathbf{f}$ & $\%$ \\
\hline $\begin{array}{l}\text { Farmall, hand } \\
\text { tractors, } \\
\text { rotavator, toner }\end{array}$ & 2 & 20.00 & 4 & 40.00 & 2 & 20.00 & 4 & 40.00 & 4 & 40.00 & 16 & 32.00 \\
\hline Carabao & 2 & 20.00 & 2 & 20.00 & 2 & 20.00 & 1 & 20.00 & 2 & 20.00 & 9 & 18.00 \\
\hline Both & 6 & 60.00 & 4 & 40.00 & 6 & 60.00 & 5 & 50.00 & 4 & 40.00 & 25 & 50.00 \\
\hline Total & 10 & 100.00 & 10 & 100.00 & 10 & 100.00 & 10 & 100.00 & 10 & 100.00 & 50 & 100.00 \\
\hline
\end{tabular}

Though the use of mechanized farm implements was evident, thirty-two (32\%) of growers still used carabao in other land preparation activities such as harrowing and plotting of furrows. For $18 \%$ small scale farmers who owned a carabao, the animal's help was already sufficient for land preparation. Since rotavator machine and even rentals were also costly, land preparation can be done manually as mentioned previously.

For those who maintained large farmlands, farm machinery were more advantageous them to save time and money. A survey revealed that $50 \%$ of growers used a combination of farm machinery and drafted animals, the carabao. Usually, they used a rotavator for plowing and harrowing, while the carabao was for plotting furrows.

\section{Farm Machinery}

The maintenance of these farm implements was lower than that of carabao, but because land preparation in calamansi farming typically took 10 years to do again, most farmers did not invest in this form of machinery. This was such if they were only engaged in calamansi farming and not in cultivating other crops. These machines and animals were rented only during the preparation of the land. Apart from the fact that rates were high, additional money would also be required to sustain them. But for those who also planted other crops, such as vegetables and palay, they spent money in purchasing these machines and drafted animal. The price of carabao was between P50,000.00 and P90,000.00, the hand tractor was between P50,000 and P70,000.00 and the rotator was between P86,000.00 and P100,000.00 Prices had no difference, but the maintenance of equipment was lower than that of the animal. The advantage of the mechanized farming was the time saved due to family labor, especially when the rotavator and toner were used to refine soil. The disadvantage in using the carabao was the long hours of work which lasted from $5-7$ hours per day.

Farm machines and equipment play an important role in calamansi production especially in land preparation. Some farmers owned their own equipment, while others did not have any. Table 5 presents the ownership of farm machines and equipment.

Table 5. Growers' Ownership Proportion for Farm Machines and Equipment

\begin{tabular}{|c|c|c|c|c|c|c|c|c|c|c|c|c|}
\hline \multirow{2}{*}{$\begin{array}{c}\begin{array}{c}\text { Form of } \\
\text { Ownership }\end{array} \\
\text { Items }\end{array}$} & \multicolumn{2}{|c|}{$\begin{array}{c}\text { San } \\
\text { Leonardo }\end{array}$} & \multicolumn{2}{|c|}{ Cabanatuan } & \multicolumn{2}{|c|}{ Palayan } & \multicolumn{2}{|c|}{ Cabiao } & \multicolumn{2}{|c|}{ Peñaranda } & \multicolumn{2}{|c|}{ Total } \\
\hline & $\mathrm{f}$ & $\%$ & $\mathrm{f}$ & $\%$ & $\mathrm{f}$ & $\%$ & $f$ & $\%$ & $f$ & $\%$ & $\mathrm{f}$ & $\%$ \\
\hline Owned & 4 & 40.00 & 5 & 50.00 & 4 & 40.00 & 5 & 50.00 & 4 & 40.00 & 22 & 44.00 \\
\hline Rented & 6 & 60.00 & 5 & 50.00 & 6 & 60.00 & 5 & 50.00 & 6 & 60.00 & 28 & 56.00 \\
\hline Total & 10 & 100.00 & 10 & 100.00 & 10 & 100.00 & 10 & 100.00 & 10 & 100.00 & 50 & 100.00 \\
\hline
\end{tabular}


Twenty-two (22) for every 50 calamansi growers owned the farm machines and equipment used in farming, while twenty-eight (28) of them merely rented.

Growers' reason for renting was that they needed this equipment once only in a decade. Another thing was that some cannot afford the cost of these machines and animal. A mini tractor costs between P 20,000.00- P 80,000.00 while the large ones are between P500,000 to $2 \mathrm{M}$. The practice of renting and sharing facilities contributes to the maximum use of these farm implements with a minimal rent pay for the maintenance of the machines.

\section{Planting Activities}

Planting activities include transplanting the seedlings to planting holes. Calamansi growers hired laborers during planting activities. Table 6 presents the source of farm laborers.

Table 6. Sources of Farm Laborers during Planting Activities

\begin{tabular}{|c|c|c|c|c|c|c|c|c|c|c|c|c|}
\hline \multirow{2}{*}{$\begin{array}{c}\text { Sources } \\
\text { Items }\end{array}$} & \multicolumn{2}{|c|}{$\begin{array}{c}\text { San } \\
\text { Leonardo }\end{array}$} & \multicolumn{2}{|c|}{ Cabanatuan } & \multicolumn{2}{|c|}{ Palayan } & \multicolumn{2}{|c|}{ Cabiao } & \multicolumn{2}{|c|}{ Peñaranda } & \multicolumn{2}{|c|}{ Total } \\
\hline & $\bar{f}$ & $\%$ & $\mathrm{~F}$ & $\%$ & $\mathrm{~F}$ & $\%$ & $\mathrm{f}$ & $\%$ & $\mathrm{f}$ & $\%$ & $\mathrm{f}$ & $\%$ \\
\hline Within & & & & & & & & & & & & \\
\hline $\begin{array}{l}\text { Family (among } \\
\text { family members }\end{array}$ & 4 & 40.00 & 5 & 50.00 & 5 & 50.00 & 5 & 50.00 & 3 & 30.00 & 22 & 44.00 \\
\hline $\begin{array}{l}\text { Within the } \\
\text { municipality or } \\
\text { place } \\
\text { cultivation }\end{array}$ & 4 & 40.00 & 4 & 40.00 & 4 & 40.00 & 3 & 30.00 & 5 & 50.00 & 20 & 40.00 \\
\hline $\begin{array}{l}\text { Outside the } \\
\text { municipality or } \\
\text { place } \\
\text { cultivation of }\end{array}$ & 2 & 20.00 & 1 & 10.00 & 1 & 10.00 & 2 & 20.00 & 2 & 20.00 & 8 & 16.00 \\
\hline Total & 10 & 100.00 & 10 & 100.00 & 10 & 100.00 & 10 & 100.00 & 10 & 100.00 & 50 & 100.00 \\
\hline
\end{tabular}

The larger percentage of hired laborers was among the family members of the growers. However, workers still needed to be employed, particularly when the area of cultivation was big such as the respondent's farmland in Mayapyap Norte, which is more or less 12 hectares. To conclude the job within a shorter amount of time, additional manpower was required, typically from within the community or barangay. If it was still inadequate, the place of cultivation was outside. But it was enough for small-scale farmers who owned half a hectare of family land to carry out farm activities just like those calamansi growers from Brgy. Obrero.

\section{Transplanting of Seedlings}

In calamansi farm establishment, different planting patterns or planting arrangements can be enforced. Among the top five producing cities and municipalities, the most common types are square and rectangular forms.

Except that a rectangle has two sets of opposite sides having varying dimensions, the rectangular arrangement is identical to a square pattern.. Usually, the grower sets a distance of $4 \times 3.5$ meters using this pattern. Majority of the growers used the square form. Distances of 4 x 4 and $3 \times 3$ meters are the common distances on this type. According to an agriculturist, farmlands that employ square planting have a possibility that the canopies of adjacent trees will overlap in time. As a result, light penetration will be hampered and growers will resort to 
thinning, removing excess plants to widen the distances of the remaining plants. This was done by growers who already have 7-10 year old calamansi trees.

This activity was another laborious and costly activity in calamansi production. Table 7 presents the transplanting cost per hectare in top five cities and municipalities in the province.

Table 7. Transplanting Cost per Hectare

\begin{tabular}{ccccccccccc}
\hline & San Leonardo & \multicolumn{2}{c}{ Cabanatuan } & \multicolumn{2}{c}{ Palayan } & \multicolumn{2}{c}{ Cabiao } & \multicolumn{2}{c}{ Peñaranda } \\
\hline Year & $\begin{array}{c}\text { No. of } \\
\text { Laborers }\end{array}$ & $\begin{array}{c}\text { Contract } \\
\text { Amount } \\
\text { /Ha. }\end{array}$ & $\begin{array}{c}\text { No. of } \\
\text { Laborers }\end{array}$ & $\begin{array}{c}\text { Contract } \\
\text { Amount } \\
\text { /Ha. }\end{array}$ & $\begin{array}{c}\text { No. of } \\
\text { Laborers }\end{array}$ & $\begin{array}{c}\text { Contract } \\
\text { Amount } \\
\text { /Ha. }\end{array}$ & $\begin{array}{c}\text { No. of } \\
\text { Laborers }\end{array}$ & $\begin{array}{c}\text { Contract } \\
\text { Amount } \\
\text { /Ha. }\end{array}$ & $\begin{array}{c}\text { No. of } \\
\text { Laborers }\end{array}$ & $\begin{array}{c}\text { Contract } \\
\text { Amount } \\
\text { /Ha. }\end{array}$ \\
2019 & $3-5$ & P2,500 & $3-5$ & P3,000 & $3-5$ & P3,000 & $3-5$ & P2,500 & $3-5$ & P2,500 \\
2018 & $3-5$ & P2,500 & $3-5$ & P3,000 & $3-5$ & P3,000 & $3-5$ & P2,500 & $3-5$ & P2,500 \\
2017 & $3-5$ & P2,500 & $3-5$ & P3,000 & $3-5$ & P3,000 & $3-5$ & P2,500 & $3-5$ & P2,500 \\
2016 & $3-5$ & P2,500 & $3-5$ & P3,000 & $3-5$ & P3,000 & $3-5$ & P2,500 & $3-5$ & P2,500 \\
\hline
\end{tabular}

Cabanatuan and Palayan City's total cost was the highest and lowest in the three (3) municipalities. The cost depended on the demand, quantity of hired labor, and prevailing wage rate in the municipalities.

\section{Farm Maintenance}

As part of the production, farm maintenance includes pruning, weeding, and irrigating the calamansi tree.

\section{Pruning}

To eradicate surplus, diseased and dead branches, pruning should be used to. To maximize light penetration, three to five lateral branches in the spiral arrangement are allowed to develop starting from about $1 \mathrm{ft}(30 \mathrm{~cm})$ from the trunk base. Pruning may also be done to limit expansion of the tree canopy.

In order to maximize the size of the tree that would be able to grow more fruit, fruit production will be delayed in the early years. This includes the pruning of flowers and fruitlets or the intentional elimination of flowers and fruitlets to enable food concentration in the growing vegetative components.. Usually, the growers used to cut those spiny branches, commonly known to them as "mandarin." This is an unhealthy characteristic of branches and leaves. They will not produce flowers and bear fruits. The sign of healthy trunks are those circular and smooth in form. Agriculturists suggest pruning calamansi trees between February and April. After April, growers should avoid pruning. From May onwards, temperature rises and pruning trees would expose the branches to harsh sunlight which then becomes harmful to them. Table 8 presents the pruning cost per hectare in the top five producing cities and municipalities.

Table 8. Pruning Cost per Hectare

\begin{tabular}{ccccccccccc}
\hline & \multicolumn{2}{c}{ San Leonardo } & \multicolumn{2}{c}{ Cabanatuan } & \multicolumn{2}{c}{ Palayan } & \multicolumn{2}{c}{ Cabiao } & \multicolumn{2}{c}{ Peñaranda } \\
\hline Year & $\begin{array}{c}\text { No. of } \\
\text { Laborers }\end{array}$ & $\begin{array}{c}\text { Contract } \\
\text { Amount } \\
\text { /Ha. }\end{array}$ & $\begin{array}{c}\text { No. of } \\
\text { Laborers }\end{array}$ & $\begin{array}{c}\text { Contract } \\
\text { Amount } \\
\text { /Ha. }\end{array}$ & $\begin{array}{c}\text { No. of } \\
\text { Laborers }\end{array}$ & $\begin{array}{c}\text { Contract } \\
\text { Amount } \\
\text { /Ha. }\end{array}$ & $\begin{array}{c}\text { No. of } \\
\text { Laborers }\end{array}$ & $\begin{array}{c}\text { Contract } \\
\text { Amount } \\
\text { /Ha. }\end{array}$ & $\begin{array}{c}\text { No. of } \\
\text { Laborers }\end{array}$ & $\begin{array}{c}\text { Contract } \\
\text { Amount } \\
\text { /Ha. }\end{array}$ \\
2019 & $2-3$ & P750 & $2-3$ & P900 & $2-3$ & P900 & $2-3$ & P750 & $2-3$ & P750 \\
2018 & $2-3$ & P750 & $2-3$ & P900 & $2-3$ & P900 & $2-3$ & P750 & $2-3$ & P750 \\
2017 & $2-3$ & P750 & $2-3$ & P900 & $2-3$ & P900 & $2-3$ & P750 & $2-3$ & P750 \\
2016 & $2-3$ & P750 & $2-3$ & P900 & $2-3$ & P900 & $2-3$ & P750 & $2-3$ & P750 \\
\hline
\end{tabular}


It was highest in Cabanatuan and Palayan City since cities' prevailing wage rate was higher than in municipalities. The common practice for those who were already old in the industry was to personally do the pruning. For those who employed the help of "kasama", it was part of the farm work. Some who did not have extra time to do the pruning hired workers to do the work.

\section{Weeding}

Weeding the calamansi plots was done by hand and/or applying chemicals, also known as herbicides. Farmers did both methods to ensure that the calamansi tree got all the nutrients and no other weeds share with it. The same with the pruning activity, small scale growers did it personally with family members' aid. If family members were not available, they asked someone to do the weeding and paid the worker. For those who owned big farmlands, they used chemical spray to get rid of the weeds. Those who did farming with the aid of "kasama" were also a part of farm work.

Table 9 presents the weeding cost per hectare in the top five cities and municipalities.

Table 9. Weeding Cost per Hectare

\begin{tabular}{ccccccccccc}
\hline & \multicolumn{2}{c}{ San Leonardo } & \multicolumn{2}{c}{ Cabanatuan } & \multicolumn{2}{c}{ Palayan } & \multicolumn{2}{c}{ Cabiao } & \multicolumn{2}{c}{ Peñaranda } \\
\cline { 2 - 10 } Year & $\begin{array}{c}\text { No. of } \\
\text { Laborers }\end{array}$ & $\begin{array}{c}\text { Contract } \\
\text { Amount } \\
\text { /Ha. }\end{array}$ & $\begin{array}{c}\text { No. of } \\
\text { Laborers }\end{array}$ & $\begin{array}{c}\text { Contract } \\
\text { Amount } \\
\text { /Ha. }\end{array}$ & $\begin{array}{c}\text { No. of } \\
\text { Laborers }\end{array}$ & $\begin{array}{c}\text { Contract } \\
\text { Amount } \\
\text { /Ha. }\end{array}$ & $\begin{array}{c}\text { No. of } \\
\text { Laborers }\end{array}$ & $\begin{array}{c}\text { Contract } \\
\text { Amount } \\
\text { /Ha. }\end{array}$ & $\begin{array}{c}\text { No. of } \\
\text { Laborers }\end{array}$ & $\begin{array}{c}\text { Contract } \\
\text { Amount } \\
\text { /Ha. }\end{array}$ \\
2019 & $2-3$ & P750 & $2-3$ & P900 & $2-3$ & P900 & $2-3$ & P750 & $2-3$ & P750 \\
2018 & $2-3$ & P750 & $2-3$ & P900 & $2-3$ & P900 & $2-3$ & P750 & $2-3$ & P750 \\
2017 & $2-3$ & P750 & $2-3$ & P900 & $2-3$ & P900 & $2-3$ & P750 & $2-3$ & P750 \\
2016 & $2-3$ & P750 & $2-3$ & P900 & $2-3$ & P900 & $2-3$ & P750 & $2-3$ & P750 \\
\hline
\end{tabular}

Data show that the cost of weeding was still highest in Cabanatuan and Palayan City and lower in the three municipalities. This same cost with the pruning activity was incurred in two (2) days of work. Wider farm area was noted in Palayan and Cabanatuan, which translated into higher labor cost.

\section{Irrigation}

Proper water management is critical in the growth of calamansi tree. Table 10 presents the growers' source of water supply for their calamansi farm.

Table 10. Sources of Water for Planting Activities

\begin{tabular}{|c|c|c|c|c|c|c|c|c|c|c|c|c|}
\hline \multirow{2}{*}{$\begin{array}{c}\text { Sources } \\
\text { Items }\end{array}$} & \multicolumn{2}{|c|}{$\begin{array}{c}\text { San } \\
\text { Leonardo }\end{array}$} & \multicolumn{2}{|c|}{ Cabanatuan } & \multicolumn{2}{|c|}{ Palayan } & \multicolumn{2}{|c|}{ Cabiao } & \multicolumn{2}{|c|}{ Peñaranda } & \multicolumn{2}{|c|}{ Total } \\
\hline & $f$ & $\%$ & $\mathrm{f}$ & $\%$ & $\mathrm{~F}$ & $\%$ & $\mathrm{f}$ & $\%$ & $\mathrm{f}$ & $\%$ & $\mathrm{f}$ & $\%$ \\
\hline $\begin{array}{lr}\text { Irrigation } & \\
\text { including } & \text { river } \\
\text { streams } & \text { and } \\
\text { canal } & \end{array}$ & 3 & 30.00 & 3 & 30.00 & 2 & 20.00 & 5 & 50.00 & 4 & 40.00 & 17 & 34.00 \\
\hline $\begin{array}{l}\text { Deep } \\
\text { using } \\
\text { pump }\end{array}$ & 7 & 70.00 & 7 & 70.00 & 8 & 80.00 & 5 & 50.00 & 6 & 60.00 & 33 & 66.00 \\
\hline Total & 10 & 100.00 & 10 & 100.00 & 10 & 100.00 & 10 & 100.00 & 10 & 100.00 & 50 & 100.00 \\
\hline
\end{tabular}

Thirty-four (34) for every 50 calamansi growers irrigated their trees from rivers, streams, and canals, while forty-six (46) of every 100 onion farmers used deep well. During 
the interview with calamansi growers, it was revealed that the primary source of water depended on the farms' geographical location.

Some Cabanatuan, Palayan, and Cabiao growers relied on rivers and canals because of the farms' geographical location being surrounded by mountains where natural water springs and canals and rivers served as spillways. The practice was that a large hose was usually attached to the canal channels that follow the land's terrain to catch water by gravity. In Entablado Cabiao and Mayapyap Norte Cabanatuan, lands or "tumana" were adjacent to the river, a fuelled pump was needed to siphon the water.

As disclosed by some calamansi farmers, water sources may not be sustainable as underground water depletion was possible and so was spring water. Table 11 presents the cost of fuel per hectare using a water pump for irrigating the farmland.

Table 11. Fuel Cost per Hectare in One Cropping Using Water Pump for Farmland Irrigation

\begin{tabular}{cccccc}
\hline Year & San Leonardo & Cabanatuan & Palayan & Cabiao & Peñaranda \\
\hline 2019 & P 3000 & P 3500 & P 4000 & P 3000 & P 3500 \\
2018 & 3000 & 3500 & 4000 & 3000 & 3500 \\
2017 & 2970 & 3465 & 3960 & 2970 & 3465 \\
2016 & 2910 & 3395 & 3880 & 2910 & 3395 \\
\hline
\end{tabular}

Problems Encountered on Production

Table 12 presents the problems encountered by growers in calamansi production.

Table 12. Problems on Production Encountered by Calamansi Growers

\begin{tabular}{|c|c|c|c|c|c|c|c|c|c|c|c|c|}
\hline \multirow{2}{*}{$\begin{array}{c}\text { Problems in Production } \\
\text { Items }\end{array}$} & \multicolumn{2}{|c|}{$\begin{array}{c}\text { San } \\
\text { Leonardo }\end{array}$} & \multicolumn{2}{|c|}{ Cabanatuan } & \multicolumn{2}{|c|}{ Palayan } & \multicolumn{2}{|c|}{ Cabiao } & \multicolumn{2}{|c|}{ Peñaranda } & \multirow[t]{2}{*}{$\begin{array}{l}\text { Ave. } \\
\%\end{array}$} & \multirow[t]{2}{*}{ Rank } \\
\hline & $f$ & $\%$ & $\mathrm{f}$ & $\%$ & $\bar{f}$ & $\%$ & $\mathrm{f}$ & $\%$ & $\mathrm{f}$ & $\%$ & & \\
\hline $\begin{array}{l}\text { Lack of seminars and } \\
\text { training on calamansi } \\
\text { production to improve the } \\
\text { farmers technological } \\
\text { know-how }\end{array}$ & 10 & 100 & 10 & 100 & 10 & 100 & 10 & 100 & 9 & 90 & $98 \%$ & 1 \\
\hline $\begin{array}{l}\text { Lack of farm laborers } \\
\text { during peak season }\end{array}$ & 6 & 60 & 6 & 60 & 6 & 60 & 7 & 70 & 6 & 60 & $62 \%$ & 5 \\
\hline Pests and diseases & 7 & 70 & 6 & 60 & 6 & 60 & 8 & 80 & 7 & 70 & $68 \%$ & 3 \\
\hline $\begin{array}{l}\text { Lack of water/irrigation } \\
\text { facilities }\end{array}$ & 5 & 50 & 7 & 70 & 8 & 80 & 6 & 60 & 7 & 70 & $66 \%$ & 4 \\
\hline Poor soil condition & 5 & 50 & 6 & 60 & 7 & 70 & 6 & 60 & 5 & 50 & $58 \%$ & 6 \\
\hline Bad weather/Calamities & 7 & 70 & 7 & 70 & 7 & 70 & 7 & 70 & 7 & 70 & $70 \%$ & 2 \\
\hline
\end{tabular}

*Multiple Responses 
Among the problems encountered by growers in the production phase, lack of government assistance was included, especially for seminars and training on calamansi production. Bad weather/calamities (70\%) ranked second, pests and diseases (68\%) ranked third, lack of water/irrigation facilities $(66 \%)$ ranked fourth, lack of farm laborers during peak season $(62 \%)$, and poor soil condition $(58 \%)$ ranked fifth and sixth respectively.

All surveyed respondents except some growers in Palayan City said that from the start of their farming experience to the present day, they had not received any support from the national or even local government in terms of training and workshops calamansi production to improve their technical know-how. Pests and diseases (68\%) were widely experienced in Cabiao and San Leonardo. This can be attributed perhaps to the location because these municipalities are bounded by lands planted with palay.

Fruits were lesser though, since pests migrated to calamansi farms when this happened. Some growers also reported that the attack of pests and diseases during the trees' flowering stage and remained until the fruit harvesting time. Throughout the rainy season, they typically experienced mottling of their trees, which affected production. During the dry season, fruit flies and red mites invaded the flowers of the calamansi trees.

Table 13. Problems and Constraints Category in Terms of Low and High Production

\begin{tabular}{|c|c|c|}
\hline $\begin{array}{l}\text { Problems Encountered } \\
\text { During Low Production }\end{array}$ & $\begin{array}{l}\text { Problems Encountered During } \\
\text { High Production }\end{array}$ & $\begin{array}{l}\text { Problems Encountered Both in } \\
\text { Low and High Production }\end{array}$ \\
\hline $\begin{array}{l}\text { Insufficient } \\
\text { financial } \\
\text { resources }\end{array}$ & 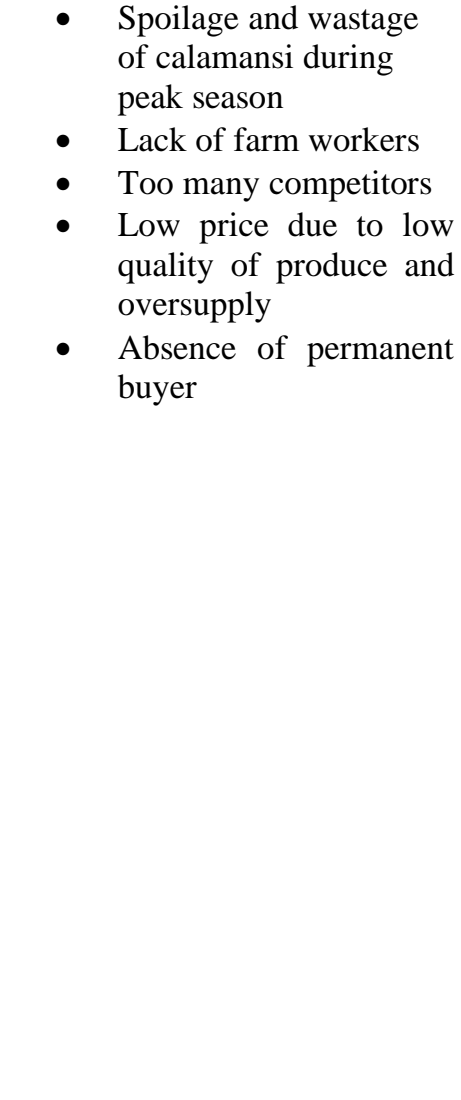 & $\begin{array}{l}\text { - High cost of seedlings } \\
\text { - } \text { High cost of fertilizers, and } \\
\text { pesticides } \\
\text { insecticides } \\
\text { - Lack of seminars and } \\
\text { training on calamansi } \\
\text { production to improve } \\
\text { the farmers } \\
\text { technological know- } \\
\text { how } \\
\text { - Poor soil condition } \\
\text { Poor farm to market } \\
\text { roads } \\
\text { Price manipulation of } \\
\text { intermediaries } \\
\text { (sakadora) } \\
\text { Frequent } \\
\text { fluctuation/unstable } \\
\text { prices } \\
\text { Pests and diseases } \\
\text { Lack of } \\
\text { water/irrigation } \\
\text { facilities } \\
\text { Price manipulation of } \\
\text { big time traders } \\
\text { Bad } \\
\text { weather/Calamities }\end{array}$ \\
\hline
\end{tabular}




\section{Conclusion \& Recommendation}

The calamansi growers utilized local seedlings, usually from the province of Batangas, inorganic fertilizers, insecticides, and fungicides, which were all costly. Some of them borrowed capital from informal lenders to finance their farm needs. The majority of them shared the same production and post-production practices, though a slight difference in labor cost was observed. Some were already in the industry for quite a long time and learned other farming techniques and practices different from the conventional and were proven effective.

Considering that the industry is quite neglected for a long time, the government may start to intervene by providing seminars and education to improve the growers' technical know-how, upgrade the water irrigation system and facilities, provide subsidies such as low-cost fertilizer, insecticides and fungicides, and find measures to stabilize the price of the calamansi fruit.

\section{Proposed Strategic Plan for Production}

Table 14 presents the proposed strategic action plan to address the problems of the calamansi growers in terms of production.

Table 14. Strategic Action Plan for Calamansi Industry in Terms of Production

\begin{tabular}{|c|c|c|}
\hline Constraints/Problems & Intervening Strategy & Responsible Group/Unit \\
\hline $\begin{array}{l}\text { Lack of seminars and training on } \\
\text { calamansi production to improve } \\
\text { the farmers technological know- } \\
\text { how }\end{array}$ & $\begin{array}{l}\text { Link growers to state universities } \\
\text { in the province, such as the } \\
\text { Central Luzon State University } \\
\text { and Nueva Ecija University of } \\
\text { Science and Technology } \\
\text { (Gabaldon Campus) that } \\
\text { specialize in agricultural } \\
\text { production and development. }\end{array}$ & $\begin{array}{l}\text { State Universities and Colleges } \\
\text { (SUCs) }\end{array}$ \\
\hline Pests and diseases & $\begin{array}{l}\text { Link growers to state universities } \\
\text { in the region or in other state } \\
\text { universities in other provinces } \\
\text { such as such as CLSU, NEUST } \\
\text { and UP Los Baños in order to } \\
\text { provide faculty-trainers } \\
\text { specialized in the field of } \\
\text { pests/insect control management. }\end{array}$ & $\begin{array}{l}\text { Department of Agriculture (DA), } \\
\text { Chemical Companies, State } \\
\text { Universities and Colleges (SUCs), } \\
\text { Local Government Unit (LGU) }\end{array}$ \\
\hline & $\begin{array}{l}\text { Link growers to the } \\
\text { City/Municipal Agriculture Office } \\
\text { in order to provide technicians } \\
\text { who can assist the growers in pest } \\
\text { management of their farms. }\end{array}$ & \\
\hline Bad weather/Calamities & $\begin{array}{l}\text { Tap the government agency } \\
\text { concerned to provide available } \\
\text { agricultural technology that could } \\
\text { detect natural disasters, such as } \\
\text { drought and typhoons, early on, in } \\
\text { order to mitigate, if not eliminate, } \\
\text { the potential risks to farmers of } \\
\text { such calamities. }\end{array}$ & $\begin{array}{l}\text { Department of Agriculture (DA), } \\
\text { Department of Science and } \\
\text { technology (DOST), National } \\
\text { Disaster Risk Reduction and } \\
\text { Management Council } \\
\text { (NDRRMC), Department of } \\
\text { Trade and Industry (DTI) }\end{array}$ \\
\hline
\end{tabular}




livelihood activities alongside
their calamansi production, such
as small-scale livestock, in order
to recover their post-disaster
losses from farming.
Lack of water/irrigation facilities
Tape concerned government Department of Agriculture (DA),
agency to consider water Department of Science and
harvesting technique such as rain Technology (DOST)
catchment system/tank for areas
that depend on rainwater sources.
Lack of farm laborers during peak
Link to "kabesilyas" from other Barangay Local Government Unit
barangays or neighbouring Growers informal organizations
municipalities
Link to Barangay Chairman of the
community if he can suggest
people living in the locality who
are in need of part-time work.
Outsource chemist or technician Department of Agriculture (DA),
that will educate the calamansi Chemical Companies, Department
growers on good soil management of Trade and Industry (DTI), State
by adding beneficial amendments, Universities and Colleges (SUCs),
which will help improve plant Private Agencies, Bureau of Soils
growth and health

a. Link growers to state universities in the province such as the Central Luzon State University and Nueva Ecija University of Science and Technology (Gabaldon Campus) that specialize in agricultural production and development.

State universities and colleges in the region, such as Central Luzon State University (CLSU) and Nueva Ecija University of Science and Technology, may provide a wide range of technical assistance and other agricultural training courses with experts available in the area. This may be freely offered to communities and organizations in need of this knowledge through their extension and research services. These universities may also outsource speakers such as technicians of multi-national companies manufacturing fertilizers and insecticide products.

Uplifting the technical skills and knowledge for this kind of business is essential because it requires scientific procedures to increase the yielding rate of calamansi tree.

b. Link growers to state universities in the region or other state universities in other provinces such as CLSU, NEUST, and UP Los Baños to provide faculty-trainers specialized in the field of pests/insect control management.

State universities such as UP Los Baños, CLSU, and NEUST Department of Agriculture can provide pest control seminars and training. Research on this subject may also be of use to agricultural communities. If farmers know best practices for pest control, they can boost their productivity and increase their profits.

a. Link growers to the City/Municipal Agriculture Office in order to provide trainings on pest management and technicians who can assist the growers in pest management of their farms

The City/Municipal Agriculture Office may conduct growers' training on pest management. They may also assign technicians to assist growers in the pest control management of their farms. 
d. Tap, the government agency concerned with providing available agricultural technology that could detect natural disasters such as drought and typhoons early on to mitigate, if not eliminate, the potential risks to farmers of such calamities.

The vulnerability of the agriculture sector to natural hazards is evident in the Philippines. The agriculture sector absorbs nearly a quarter of all damages inflicted by natural hazards such as drought, floods, and typhoons.

Preparing for such events and taking steps to reduce risks to farmers and farming systems can greatly reduce such damages and avoid the need to rebuild agriculture back from scratch following a disaster. Various farming systems are adopted by farmers allocated from the limited resources they have or face, such as land, labor, and capital, to maximize their income [6].

Through the DA, the government may invest in agricultural technologies such as farm drones that could help assess and predict the possible extent of agricultural damage a calamity may bring.

e. Training may also be provided to growers on how to engage in other livelihood activities alongside their calamansi production, such as small-scale livestock, to recover their post-disaster losses from farming.

Calamansi farming may be done alongside other livelihood activities such as smallscale livestock. These activities may augment the growers' income and be a source of funds after the occurrence of a disastrous calamity that causes damage to crops.

f. Tap the concerned government agency to consider water harvesting techniques such as rain catchment system/tank for areas that depend on rainwater sources.

The irrigation of farms in upland areas such as Palayan City is a serious problem. Water coming from the constructed dams and dikes is not accessible in these farms due to their geographical location. If an irrigation system is not feasible for the time being, the local government unit in the said area may have a rain catchment system/tank as an alternative source of water.

g. Link to "kabesilyas" from other barangays or neighboring municipalities to provide laborers during peak season

Time is a constraint; however, it is quite controllable using laborers in other barangay and municipalities. Mechanized harvesting is not yet feasible in the country. Calamansi fruits need to be harvested manually, and the only way to solve the problem is to link with other growers and farm leaders like the "kabesilya." One may also offer higher labor costs to entice laborers to prioritize such farms.

Growers may also ask the barangay chairman in their locality if he can suggest people who need gainful work.

h. Outsource chemist or technician who will educate the calamansi growers on good soil management by adding beneficial amendments which will help improve plant growth and health

Calamansi growers, with the aid of some government agencies, can outsource speakers who are experienced in the soil management of different crops. Many state-funded universities and community colleges provide agricultural education, research, and extension services for 
agricultural communities. Since they are the ones who are experts in the field of soil management, the growers would be knowledgeable on the methods on how to sustain their healthy soil for the fruit to reach its prime.

\section{Acknowledgment}

The researchers would like to acknowledge its learning institution, the Nueva Ecija University of Science and Technology, family, relatives, and friends.

\section{Conflict of Interest}

All authors declared no conflict of interest in this paper.

\section{References}

[1] Titong, R, (2020) Calamansi Juice with Camote Leaf Extract: A Product Development SSRN: https://ssrn.com/abstract=3661285 or http://dx.doi.org/10.2139/ssrn.3661285.

[2] Gracia, E.B (1992). Status and management of calamansi production in Cabanatuan City (Philippines) and its implications to famr entrepreneurship. Thesis.

[3] Jensen, F.E. and Pope, C.A., III (1987), The changing structure of US agriculture and implications for research in agribusiness firms. Agribusiness, 3: 139150. https://doi.org/10.1002/1520-6297(198722)3:2<139::AIDAGR2720030202>3.0.CO;2-9

[4] Erlyna Wida Riptanti, Masyhuri Masyhuri, Irham Irham, Any Suryantini. The ability of dryland farmer households in achieving food security in food-insecure area of East Nusa Tenggara, Indonesia[J]. AIMS Agriculture and Food, 2020, 5(1): 30-45. doi: 10.3934/agrfood.2020.1.30

[5] Ramakrishna R, Rao TR (2008) Strengthening Indian agriculture through dryland farming: Need for reforms. Indian J Agric Econ 63: 461-476.

[6] Widodo S (1998) Farming system approach for sustainable agriculture. Agro Ekonomi $\mathrm{V}: 1-6$.

[7] Jan Willem Erisman, Nick van Eekeren, Jan de Wit, Chris Koopmans, Willemijn Cuijpers, Natasja Oerlemans, Ben J. Koks. Agriculture and biodiversity: a better balance benefits both[J]. AIMS Agriculture and Food, 2016, 1(2): 157-174. doi: 10.3934/agrfood.2016.2.157

[8] Boris Boincean, Amir Kassam, Gottlieb Basch, Don Reicosky, Emilio Gonzalez, Tony Reynolds, Marina Ilusca, Marin Cebotari, Grigore Rusnac, Vadim Cuzeac, Lidia Bulat, Dorian Pasat, Stanislav Stadnic, Sergiu Gavrilas, Ion Boaghii. Towards Conservation Agriculture systems in Moldova[J]. AIMS Agriculture and Food, 2016, 1(4): 369-386. doi: 10.3934/agrfood.2016.4.369.

[9] Helmi Helmi, Hairul Basri, Sufardi, Helmi Helmi. Analysis of soil water balance and availability on several land use types for hydrological disaster mitigation in Krueng Jreu Sub-watershed[J]. AIMS Agriculture and Food, 2020, 5(4): 950-963. doi: 10.3934/agrfood.2020.4.950

${ }^{[10]}$ Branca G, Lipper L, McCarthy N, et al. (2013) Food security, climate change, and sustainable land management: A review. Agron Sustain Dev 33: 635-650.

[11] Allouche J (2011) The sustainability and resilience of global water and food system: Political analysis of the interplay between security, resource scarcity, political system and global trade. Food Policy 36: 53-58.

[12] Thamaga-Chitja JM, Hendriks SL, Ortmann GF, et al. (2004) Impact of maize storage on rural household food security in Northern Kwazulu-Natal. J Fam Ecol Consum Sci 32: $8-15$. 
[13] Joe Mari J. Maja, James Robbins. Controlling irrigation in a container nursery using IoT[J]. AIMS Agriculture and Food, 2018, 3(3): 205-215. doi: 10.3934/agrfood.2018.3.205.

${ }^{[14]}$ Espino, R. and Espino, M. (n.d.). The status of the fruit industry in the Philippines. Retrieved from http://www.fftc.agnet.org/library.php?func=view\&id=20150810090507

${ }^{[15]}$ Philippine Statistics Authority. (2018). https://psa.gov.ph/fruits-cropsbulletin/calamansi

[16] Cambridge Statistics Dictionary (2014) Processing. Cambridge University Press. https://dictionary.cambridge.org/us/dictionary/english/processing

${ }^{[17]}$ Morte, M., Arceo, L. (n.d.). Potential of calamansi (Citrofortunella microcarpa) fruit peels extract in lowering the blood glucose level of streptozotocin induced albino rats (Rattus albus). Retrieved on February 12, 2018 from http://www.ijfe.org/uploadfile/2017/0816/20170816113539776.pdf 